\title{
DEVELOPING BALANCED SCORECARD MODEL FOR VOCATIONAL HIGH SCHOOL EDUCATION
}

\author{
Apri Winge Adindo \\ STIE 66 Kendari \\ apriwingeadindo@yahoo.com
}

\begin{abstract}
The objective of the study was to find an appropriate Balanced Scorecard model to be implemented in the vocational education management and to test the effectiveness of balanced scorecard internal model for the vocational high school education. The method that the researchers implemented in the study was the research and development designed by Borg \& Gall. The data in the study were gathered by means of in-depth interview, observation and documentary analysis in the five prominent vocational high schools from the Province of Southeast Sulawesi. The informants in the study were selected by means of snowball sampling. The data validity was tested by the triangulation technique. The First Stage and the Second Stage of model validation/ experiment was implemented by means of Delphi technique and the validation/experiment of both stages involved 50 leaders from the state and the private vocational high schools in the Province of Southeast Sulawesi. The study showed that the appropriate Balanced Scorecard model for the vocational high school educational management has been a system that might be implemented for identifying and for measuring the main performance of vocational high schools through four perspectives namely the financial perspective, the customer perspective, the internal process perspective and the learning and growth perspective. Balanced Scorecard model for the vocational high school education has met the criteria of quite high internal effectiveness model and has belonged to the good criteria. As a result, the Balanced Scorecard model might be implemented as the model of vocational high school managerial implementation.
\end{abstract}

Keyword: balanced scorecard, vocational high school and vocational high school performance

\section{PENGEMBANGAN MODEL BALANCED SCORECARD UNTUK PENDIDIKAN SMK}

Apri Winge Adindo

STIE 66 Kendari

apriwingeadindo@yahoo.com

\begin{abstract}
Abstrak
Tujuan penelitian ini adalah mengembangkan model Balanced Scorecard yang cocok untuk diterapkan dalam pengelolaan pendidikan kejuruan dan menguji keefektifan internal model Balanced Scorecard untuk pendidikan SMK. Metode penelitian yang digunakan dalam penelitian ini adalah penelitian dan pengembangan (RED) rancangan Borg \& Gall. Data penelitian dikumpulkan melalui wawancara mendalam, observasi, dan analisis dokumen pada lima SMK Unggul di Provinsi Sulawesi Tenggara. Informan penelitian ditetapkan dengan snowball sampling. Keabsahan data diuji dengan teknik trianggulasi. Uji coba/validasi model Tahap 1 dan Tahap 2 menggunakan teknik Delphi dengan subjek penelitian sebanyak 50 orang pimpinan SMK dari 15 SMK Negeri dan SMK Swasta di Provinsi Sulawesi Tenggara. Penelitian ini menunjukkan bahwa model Balanced Scorecard yang cocok untuk mengelola manajemen SMK adalah suatu sistem yang digunakan untuk mengenali dan mengukur kinerja utama SMK melalui empat perspektif Balanced Scorecard meliputi perspektif keuangan, pelanggan, proses internal, pembelajaran dan pertumbuhan. Model Balanced Scorecard yang dikembangkan untuk pendidikan SMK yang diajukan telah memenuhi kriteria keefektifan internal model yang tinggi dan termasuk kategori sangat baik, sehingga layak digunakan sebagai model pelaksanaan manajemen SMK.
\end{abstract}

Kata kunci: balanced scorecard, SMK, dan kinerja SMK 


\section{Introduction}

In the era of information revolution that has been in progress nowadays, companies or organizations encounter environmental changes with far different characteristics in comparison to the previous era. In the era of industrial revolution, the competitive edge of a company or an organization was determined by the level of efficiency in allocating the human resources or the tangible assets that might be easily elaborated in the financial dimension. On the contrary, in the era of informational revolution the measures on the competitive edge of a company or an organization heavily depend on the capacity of the company or the organization to mobilize and to explore the intangible resources/ assets and the human's intellectual wealth that might be difficult to elaborate in the financial dimension.

In relation to the situation above, Indonesia has not benefitted much the intangible assets such as the human's intellectual wealth such as friendliness, honesty and hardwork in providing the sincere and the humble service. Based on the UNDP report regarding the Human Development Index in 2011, Indonesia was on the $124^{\text {th }}$ place out of 187 nations and scored 0.617. That result has been heavily influenced by the lack of that the managers had in understanding the existence of intangible assets namely knowledge whereas the high quality of human resources in general should be followed by the high performance as well.

The low quality of human resources impacts the low Indonesian competitive edge in the middle of global competition that covers all life aspects. One of the factors that inhibit the competitive edge attainment is the insufficient number of skilled labors. In this context, the vocational high schools that serve as the high education unit should play their role in preparing their graduates to enter the employment have not shown good performance.

The results of the observation that the researcher has conducted shows that the inoptimum performance of vocational high schools occur due to the fact that vocational high school principals have not fully understood the importance of transparency and accountability in managing the educational budget of vocational high schools. As a result, the principals have not been able to provide a clean condition in relation to the authority of spending the educational budget toward all customers (parents, communities and stakeholders) of the vocational high schools. In addition, in providing the service the vocational high schools have not provided certain values, such as responsiveness, that might encourage the vocational high schools to work effectively without abandoning the orientation toward the customers' needs. The situation is apparent in the learning process that emphasizes the cognitive and psychomotoric aspects. However, the same learning process has been lack of affective aspects whereas the affective aspects should be emphasized in order that the learning participants might understood the affective aspects well since the affective aspects are heavily demanded during the job practice and when the students have entered the employment as employees.

In preparing the learning participants to enter the employment, the vocational high schools have not had good performance in their internal management and this situation is found in the inability of vocational high schools' managerial boards to provide space and to create synergy for the extra-governmental parties such as communities, DUDI and educational stakeholders within collaborative efforts to advance the vocational high schools in order to generate output with great competencies and good competitive edge in the respective domains. For example, the managerial boards of vocational high schools hold committee meetings only for socializing the school programs and do not benefit these meetings for discussing new innovations that might be undergone for advancing the vocational high schools. The main obstacle in such efforts lies in the human resources of vocational high schools who have not 
updated their knowledge toward the science development both inside and outside their domain; in other words, the insights of these human resources have been less expanded. Besides, the vocational high school principals have not implement the managerial control systems for monitoring and evaluating the implementation of strategic plans that have been designed.

Based on the problems that have been explained above, the decisions that have been taken by the principals miss the targets. These problems also further show that the unidimensional information system that has beeen limited to the financial benchmark has not been sufficient to mobilize and to explore the resources that mostly are in the form of intangible assets. For converting the unidimensional information system into the multidimensional information system, Kaplan \& Norton (1992) have designed a comprehensive measurement system known as the Balanced Scorecard. Robbins \& Coulter (2010, p. 195) state that Balanced Scorecard typically views the four areas that contribute to the performance of a company and the areas are as follows: finance, customer, internal process and humane/innovative/ developmental assets.

The Balanced Scorecard as a performance measurement system might be implemented as a tool for controlling, analyzing and revising an organization (Campbell, Datar, Kulp, \& Narayanan, 2002). Originally the Balanced Scorecard is implemented as the performance measurement tool for business organizations. However, in the further development the Balanced Scorecard is also implemented by the public organizations including the educational ones.

Robert S. Kaplan in a program named Face to Face with Desi Anwar, (2013) by Metro TV (accessed on February 26 $6^{\text {th }}, 2013$ ) stated that originally the Balanced Scorecard should mainly be implemented as a measurement performance system in the business organizations. However, after the Balanced Scorecard has been implemented by multiple organizations the Balanced
Scorecard might also be implemented by the public organizations including the educational ones. The Balanced Scorecard has been considered to be appropriate for the governmental organizations as well because the Balanced Scorecard does not only emphasize the quantitative-financial aspects but also the qualitative-non-financial aspects. This aspect is in accordance with the organizational governments especially the educational ones that put the profit not only as the main performance measure but also the qualitatve and nonfinancial service.

The Balanced Scorecard then evolves again into a strategic management system. Here, the Balanced Scorecard puts forward the strategy as the center of managerial process. David (2009, p. 247) also defines the Balanced Scorecard as a technique of strategy and evaluation control. The name Balanced Scorecard has been selected due to the belief regarding the company's needs to balance the financial measures that are have often been implemented in evaluating and controlling the strategies with multiple non-financial measures such product quality and customer service. The Balanced Scorecard has also been compared to a dashboard that is expected to mobilize and to explore the resources that an organization has harmoniously within the process of strategy implementation.

An organization that implements the strategic management has clear and traceable strategic plans and operational plans. The strategic management also assists the leaders to have better, more careful, more directed and clearer plans so that the leaders will be easier to predict and to project the future and the strategies in order to achieve the organizational objectives more realistically. The same benefit also applies for the non-profit organizations including the governmental organizations especially in the educational domain. Therefore, in order to solve the problems the vocational high schools demand a system that might be implemented for identifying and measuring the main perfor- 
mance of vocational high schools namely the Balanced Scorecard.

The benefit of Balanced Scorecard in the educational domain might be seen, for example, in the university management. In relation to the statement, the educational management of vocational high schools is not different much than that of universities and of organizations in general. Therefore, the Balanced Scorecard is suspected to be effective for the educational management of vocational high schools.

As a system that is implemented for identifying and measuring the main performance of vocational high schools through the financial perspective, the customer perspective, the internal process perspective and the learning and growth perspective, the Balanced Scorecard has several advantages: (a) the vocational high schools might take the responsibilities with regards to the authority of educational budget and resources expenditure in a more effective and efficient way as well as the creation of transparency and accountability in the vocational high schools in accordance to the expectation of the educational customers and stakeholders for the sake of achieving the missions of vocational high schools; (b) the vocational high schools might meet the expectations of the customers, namely the educational internal and external stakeholders, by means of value added that should be provided by the vocational high schools; (c) the vocational high schools might compete in a healthy way from one to another by improving the educational input-output quality through the the prominent working process in order to meet the expectations of the educational customers and stakeholders; and (d) the vocational high schools might develop the human resources by means of learning innovations and the quality of working process in overall from the strategic level to the operational level objectively.

Based on the explanations in the previous paragraphs, the objectives of the study are as follows: (a) to describe the principles of Balanced Scorecard that might be implemented in the vocational high schools; (b) to define a model of leadership, managerial and communication skills implementation for the vocational high school principals in the Balanced Scorecard-based vocational education management; (c) to develop the Balanced Scorecard model that might be appropriately implemented in the vocational education management; and (d) to test the internal effectiveness of the Balanced Scorecard model for the vocational high school education. The resulted Balanced Scorecard model for the vocational high school education might be implemented for identifying and measuring the main performance of vocational high schools through the following four perspectives: the financial perspective, the customer perspective, the internal process perspective and the learning and growth perspective. The increasing performance of vocational high schools is expected to improve the educational service such as the budget transparency within the educational domain in order to generate prominent vocational high school graduates with the appropriate regulations and the appropriate regulations should be implemented in uncovering the multiple resources that the organizations have. Later, the multiple resources will be functioned in the form of actual programs for improving the educational quality.

\section{Method}

The method that the researcher implemented in the study was the research and development design by Borg \& Gall (1983, p. 775) that included the following ten stages: (1) research and information collecting; (2) planning; (3) developing preliminary form of product; (4) preliminary field testing; (5) main product revising; (6) main field testing; (7) operational product revising; (8) operational field testing; (9) final product revising; and (10) disseminating and implementing. In general, the research and development study would be conducted in two stages. The first stage was intended to attain the preliminary information or the Balanced Scorecard mo- 
del in the vocational high schools. Then, the second stage was to test the model or to validate the results of development that had been found fro the first stage.

\section{Research and Information Collecting}

This stage consisted of two activities namely the field study and the literatur review. The field study was intended to find the empirical information from the site that had been selected. The data and the information that had been attained then would be implemented as the basis for developing the preliminary model of Balanced Scorecard implementation for the vocational high school educations. In addition the model development would also be performed by means of relevant literature review with regards to the theory, the practice, the results of study and the laws and regulation of educational management.

The design that would be implemented for identifying the Balanced Scorecard model in the vocational high schools was the qualitative study. Sugiyono (2009, p. 205) stated that the problems in the qualitative study had not been clear, had been vague and had been complex and dynamic. The problems of Balanced Scorecard model in the vocational high schools that would be identified in the study had not been definitive, had been temporary and had been tentative. Therefore, the most relevant approach for gathering the data in the field would be the qualitative approach. The data were gathered by means of interview, documentation and observation. The locations that the researcher selected for the study were five vocational high schools in the Province of Southeast Sulawesi namely Negeri 1 Kendari State Vocational High School, Negeri 3 Kendari State Vocational High School, Negeri 1 Unaaha State Vocational High School, Negeri 1 Kolaka State Vocational High School and Negeri 1 Baula State Vocational High School. The data from the Office of Education for the City of Kendari in 2013 showed that the five state vocational high schools had been the best and the prominent schools in the Province of Southeast Sulawesi. The promi- nence of the five vocational high schools were apparent from the following benchmarks: (a) the achievement of ISO: 90012000 Certificate; (b) the governmental recognizition for being the prominent vocational high schools; and (c) the achievement of A-status school accreditation that had been awarded by the Board of National Accreditation (Badan Akreditasi Nasional). The benchmarks were stipulated in order to attain more documented information regarding the managerial profile of vocational high school institutions. The informants in the study were selected by means of snowball sampling. Then, the instrument in the qualitative study were researcher herself. The data validity would be tested by means of triangulation technique.

Planning

This stage was focused to: (1) formulate the objectives of model development, in this case the Balanced Scorecard model for the vocational high school education; (2) stipulate the targeted model users, namely the vocational education providers or the other school institutions that might benefit the Balanced Scorecard model for the vocational high school education; and (3) decide the model components, namely the model components that would ease the users to implement the model.

Developing the Preliminary Form of Product

In this stage, the researcher would design a new system of Balanced Scorecard model development for the vocational high school education complete with the specification. Then, the model would be put into a feasibility test by involving 18 people who had good expertise competence both theoretically an practically in terms of Balanced Scorecard model implementation for the vocational high school education. Based on the experts' and the practitioners' opinion and judgement, the researcher would revise the development of Balanced Scorecard model for the vocational high school education. 


\section{Preliminary Field Testing}

The preliminary field testing of Balanced Scorecar model development for the vocational high school education was intended to test whether the developed model had met the already stipulated model specifications or not. The first stage of preliminary field testing was conducted in a limited manner toward three vocational high schools and involved 18 educational practitioners who had been experienced in implementing the vocational high school education management. The subjects in the first stage of preliminary field testing were the principals and the vice principals. The subjects were selected by implementing the Delphi technique. In addition, the preliminary field testing was also intended to gather essential feedback and suggestions for revising the model so that the model would meet the already stipulated specifications.

\section{Main Product Revising}

Based on the results of limited preliminary field testing, the researcher revised the preliminary product design (the figure of preliminary field Balanced Scorecard model development design). The results of the revision were the main field product design of the Balanced Scorecard model development for the vocational high school education and the model design later was tested toward the expanded number of subjects.

\section{Main Field Testing}

The model that had been designed based on the first stage of preliminary field testing would be implemented in the main field testing. The main field testing (the second stage of preliminary field testing) was conducted toward ten vocational high schools with 50 subjects; these schools were divided into two groups namely the public vocational high schools and the private vocational high schools. The researcher selected the experiment methods for the main field testing or the second stage of preliminary field testing. The results of the main field testing then were used for im- proving the Balanced Scorecard operational model development for the vocational high school education.

\section{Operational Product Revising}

Based on the data analysis and the records during the second stage of testing or the main field testing, the researcher enhanced the main field design for the development of Balanced Scorecard model for the vocational high school education so that the researcher would generate a new model and this stage was named as Operational Product Revising. The final result of this stage was the operational design of Balanced Scorecard model for the vocational high school education and the effectiveness of the newly designed model would be tested to the expanded number of subjects.

\section{Operational Field Testing}

The effectiveness of the model that had been attained from the results of operational product revising would be tested to the actual targets namely the vocational high school education managers as the candidates of model users. In the effectiveness testing, the researcher selecxted 15 vocational high schools as the targets and involved 50 subjects who came from two different vocational high school groups namely the public vocational high schools and the private vocational high schools. The instruments in the Balanced Scorecard model for the vocational high school education contained three items of modeal feasibility criteria indicators namely: (1) easy understanding; (2) practical implementation of guidelines; and (3) model effectiveness. The results of effectiveness test analysis and the suggestions on the operational product revision then would be implemented for revising the final product of Balanced Scorecard model development for the vocational high school education.

\section{Final Product Revising}

In this stage, the researcher revised the final stage of the product based on the results of data analysis from the effective- 
ness test of Balanced Scorecard model development operational design for the vocational high school education. The revision was conducted toward the weaknesses that still had been found in each of model components. The final result would be the Balanced Scorecard model development product for the vocational high school education that had been tested and that had internal effectiveness.

\section{Disseminating}

Product disseminating was the final stage of the model development process. The targets of Balanced Scorecard model development product disseminating for the vocational high school education were the vocational schools that woudl implement the results of the study, the policyholders and the professional people in the vocational education management. The product disseminating efforts would be conducted as follows: (1) composing a report regarding the product results; (2) providing the results of the study in an article sent to the national and international journals; and (3) socializing the model product in the study through a scientific forum.

\section{Results and Discussions}

The results of the study in the first stage showed that the principals had implemented the Balanced Scorecard both implicitly and explicitly. Implicitly, the principals had implemented the Balanced Scorecard by means of School's Self Evaluation (Evaluasi Diri Sekolah or also known as EDS). The EDS assessed the quality of educational provision based on the key indicators that had been stipulated by the government namely the eight National Education Standard (Standar Pendidikan Nasional or also known as SNP) that consisted of standard of content, standard of learning process, standard of educators and educational staffs, standard of funding, standard of management, standard of assessment and standard of graduates competencies; theself-evaluation assessed the actual standards and verified these standards by means of appropriate physi- cal evidence. The information on the school performance that had been attained would be turned into the basis of preparing the School Development Plan (Rencana Pengembangan Sekolah or also known as RPS) and the School Budget, Income and Expenditure Plan (Rencana Pendapatan Anggaran dan Belanja Sekolah or also known as RAPBS). The measurement of vocational high school performance by means of EDS definitely would be different if the measurement process implemented the Balanced Scorecard model.

The use of Balanced Scorecard in the vocational high school institution management should have more orientation toward the strategic management and the operational (tactical) management and the orientation might be shown by the association between the long-term objectives (vision through mission) of the vocational high schools and the short- or the mid-term objectives of the vocational high schools. Therefore, the vision of vocational high schools that would be attained through the mission of the vocational high schools might be elaborated empirically so that the vision might be performed in the form of daily operational activities. In order that the vocational high school institutions might execute their operational activities equally, the vocational high school institutions should have certain strategies. The strategies might empower the vocational high schools to improve their performance not only in one aspect, namely the financial aspect, but also in the non-financial aspect (the intangible asset) and in the sustainable achievement. On the other hand, explicitly the educational service in the vocational high schools provided by the principals had met the minimum standards that had been stipulated by the government (the SNP) integratively into the four perspective of Balanced Scorecard namely the financial perspective, the customer perspective, the internal process perspective and the growth and progress perspective.

Then, from the results of the second stage testing the researcher would like to focus the attention more on the field testing 
and the model revision. Based on the data of model effectiveness test, the researcher found that the Balanced Scorecard model for the vocational high school education had earned good score in the easy understanding (89.23, belonged to the good category), good score in the practicality and feasibility (89.44, belonged to the good category) and very good model effectiveness score (90.21, belonged to the very good category). These results indicated that the Balanced Scorecard model for the vocational high school education that had been developed in the study had been considered effective for assisting the managers in identifying and in measuring the main performance of vocational high schools throught four perspectives namely the financial perspective, the customer perspective, the internal process perspective and the growth and progress perspective.

Next, based on the results of Balanced Scorecard model effectiveness for the vocational high school education the researcher gathered feedback that would also be turned into the basis of model revision. In relation to the model revision, there were changes in several parts of the model and one of the changes lied in the role of principals in implementing the Balanced Scorecard concept withn the SNP management. The revision was conducted by improving the flowchart so that there would be a form of association among the principals, the Balanced Scorecard concept and the SNP. In addition, the researcher also revised the role of Balanced Scorecard in identifying and in measuring the main performance of vocational high school through the four perspectives namely the financial perspective, the customer perspective, the internal process perspective and the growth and progress perspective in the managerial control system during the implementation of strategic planning. In order that the organizations' strategies might be effectively and efficiently implemented during the achievement of organizational objectives, the vocational high school might need a managerial control system. The recent approach of managerial control system would be the Management Control System (also known as MCS) that had been developed by N. Anthony.

Anthony \& Govindarajan (2007, p. 2) stated, "Management controlis a process by which manager influence other member organization to implement the organization's strategies." In other words, management control had been a process in which a manager influenced the organization members to implement strategies that had been stipulated by the organization. Furthermore, the basic principle of MCS would be added to the revision by putting a control system that would function if there was deviation between the job standards and the performance. Whenever there was deviation, the affector would analyze the causes of deviation, would select the actions that might be considered effective and would implement and measure the results of related action. In addition to the main revision, the researcher also perfor-med small revisions, such as the mystiping errors, so that the researcher generated the final feasible Balanced Scorecard model for the vocational high school education as the vocational high school management model. The model would be explaine in Figure 1.

Based on Figure 1, the Balanced Scorecard-based strategic management system had been a system that might be benefitted by the vocational high school principals in managing strategically an educational organization that they led. The educational organization management was strategically very important because the educational organization management might provide direction and might decrease the future uncertainty within the educational provision pursued by the educational practitioners. The educational organizations, especially the vocational high schools, had been the organizations which main task was to provide the wellqualified educational service to the society; in other words, the educational service provided by the vocational high schools should meet the eight SNP criteria. 


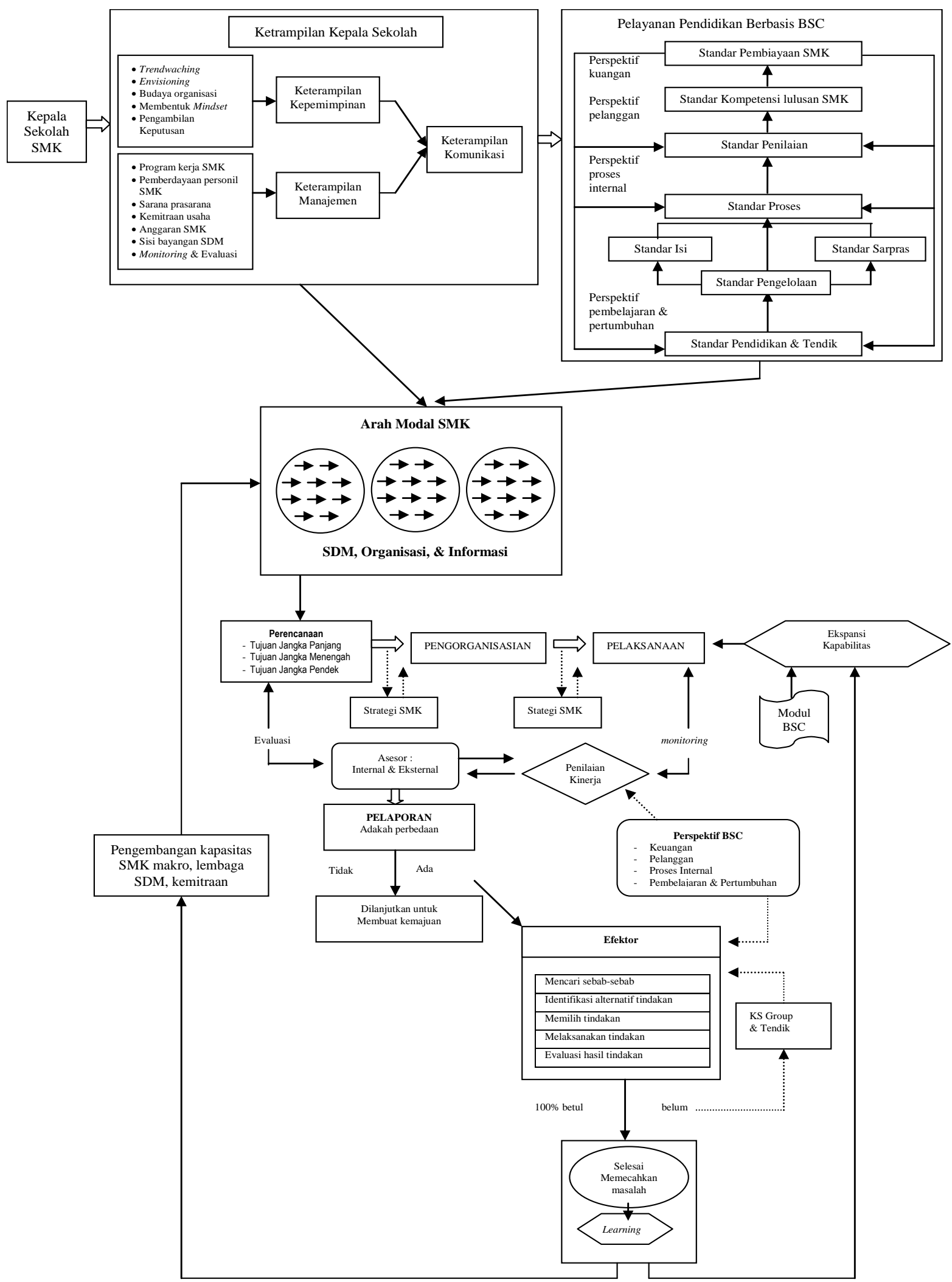

Figure 1. Balanced Scorecard Model for the Vocational High School

Most of the success achieved by an organization had been dependent on the managers. If the managers performed their jobs well, then organizations might accomplish their objectives. In this study, the managers in the study were the school principals. The principals were demanded to be able to use their skills appropriately and the skills included the communication skill, the managerial skill, the communi- 
cation skill in integrating the Balanced Scorecard concept, the interpersonal skill and the technical skill; these skills were necessary for providing the well-qualified education and these skills were also related to: (1) trend-watching development; (2) envisioning developmet; (3) organizational culture development; (4) mindset formation; (5) decision making activity; (6) vocational high school working program management; (7) educators and educational staff empowering management; (8) facility management; (9) business partnership management; (10) vocational high school budget management; (11) educators and educational staffs side aspect management; and (12) monitoring management.

The eight Balanced Scorecard-based SNP criteria were integrated into the strategic management system in order to improve the organizational performance and these criteria had impact toward the two aspects of planning system and management planning namely: (1) the planning system and the management planning by improving the planning quality significantly; and (2) the structure of planning system and management planning by improving the managerial quality of personnel performance. The good educational planning and control system capacity might be beneficial both for the short-term, the mid-term and the long-term educational objectives that would be achieved and for the control upon the implementation and the control upon the organizational plan implementation.

The success of an organization, namely a vocational high school, in managing the performance might be seen from the school's input-output. The managerial planning and control system was implemented in order to encourage the organization to be able to conduct the main activity and the to manifest the organization as the performance multiplying system. In order to realize this aspect, the vocational high schools' managerial planning demanded the human capital, the organizational capital and the information capital.
In relation to human capital, Mathis \& Jackson (2009, p. 113) stated that individual performance, motivation and employee retention had been the main factors for an organization to maximize the effectiveness of individual human resources. Therefore, the performance should be well managed. The performance management that had been conducted in order to achieve success was called as performance management. According to Armstrong (2003, p. 293), performance management had been a strategic and integrated approach for generating continuous success by improving the performance of the people who worked in an organization and by developing the capability of the contributing team and individuals.

The human capital, the organization capital and the information capital became the sources of human resources consumption or emppowerment only for providing the value added for the customers and the activities of producing service might be implemented in a cost effectively manner. The organization performance also demanded strategies, objectives and integration from input-output into the cause-effect relationship in order to accomplish the school's objectives as having been expected. The harmony of objectives and strategies heavily determined the success of school management in managing and in improving the school's performance in the future. Therefore, in order to overcome the challenge Kaplan \& Norton (2010, p. 225) proposed the importance of communication that should be conducted by the leaders. The leaders should communicate the mission, the values, the vision and the strategies and this communication would be the first step for encouraging the mautivation among the employees. An effective communication would be very important for the implementation of BSC. The leaders should have communication for at least seven times under seven different manners with the employees in order to adjust the implementation and the strategy.

The importance of communication had also been proposed by Rustomji \& 
Parkinson (1993, pp. 66-72), who stated that communication demanded coordination for a supervisor. A manager might be very effective if he or she had good communication skills. The main tasks of a manager would be establishing relationship with the employees, encouraging the employees to perform their orders and delivering the orders into the wider level. An effective manager should be skillful in delivering his ideas to the other people and should also be able to understand other people's mind.

In order that the harmony between the objectives and the strategies that had been stated in the planning process might gain success during the implementation stage, the leaders/the school principals should have strong role in coordinating, mobilizing and harmonizing all of the available educational resources. The school principals' leadership had been one of the factors that might encourage the schools to manifest the vision, the mission, the objectives and the targets of the schools through the programs that should be implemented in a well-planned and sequential manner.

In more detailed statement, Mulyadi (2007, pp. 883-884) divided the leadership skills and the managership skills into the stages of managerial planning and control stage for a company that might be applied into the domain of education. The leadership skills would be necessary in the system of strategy formulation and the system of strategic planning. In the system of strategy formulation, the leadership skills would be necessary for: (1) trendwatching, namely reading the trend of macro-environment changes; (2) SWOT analysis, an analysis technique that had been implemented for identifying the opportunity and the threat from the external environment as well as the company's strength and internal weakness; (3) envisioning, namely reconfirming or redefining the mission, the vision, the objectives, the fundamental belief and the fundamental value of the company; and (4) strategy selecting namely selecting the pattern of overall organizational resources empowerment and mobi- lization in order to manifest the organization's vision. In a strategic planning system, the leadership skills would be necessary: (1) interpreting the vision, the mission, the fundamental belief, the fundamental values and the strategy into the company's scorecard that contained the strategy map, the scorecard and the action plan for the company in overall; (2) cascading the company scorecard into the mission center scorecard, cascading the mission center scorecard into the service center scorecard and cascading the mission center scorecard and the service center scorecad into the team scorecard and the personnel scorecard. The system of strategy formulation and the system of strategic planning was related to the planning of changes toward the direction that the company had not experienced previously. Thereby, both systems were related to the company effectiveness in describing the company condition in the future that would be manifested. In other words, both systems demanded the leadership skills.

On the other hand, the managership skills were demanded in the system of program design, the system of budget proposal, the system of implementation and the system of monitoring. The four systems demanded regularity in manifesting the changes that had been stipulated in the system of strategy formulation and the system of strategic planning. Therefore, both systems also demanded the managership skills.

In relation to the theoryof educational leadership that had been explained above, the researcher found that in the performance management of vocational high school institutions by means of Balanced Scorecard approach a principal demanded the leadership skills, the managerial skills and the communication skills. The implementation of leadership skills in the Balanced Scorecard-based vocational high school management should make use of the transformational leadership approach. The results of a study by Hendrawati \& Prasojo (2015, p. 157) showed that the principal's transformational leadership, the 
school's cultures and the teachers' job motivation provided significant contribution toward the variable of students' learning achievement namely $18.907 \%$. The implementation of school principal's leadership skills by means of transformational leadership approach was shown by the visionary actions in leading the educational institution and the visionary actions were as follows: (1) developing the trendwatching efforts in order to map comprehensively the environment that the educational institution would encounter in the future; (2) developing the envisioning efforts by benefitting the SWOT analysis in order to decide the school's vision, mission, fundamental belief, fundamental values and strategies; (3) developing the organizational cultures; (4) establishing a mindset in order that the school personnel would open their insight and would be willing to follow the change; and (5) making decisions. The five visionary actions were managed by the principals of the Balanced Scorecard-based schools that defined the vocational high schools as the center of management and that had more orientation toward the learning and growth perspective. In this case, the school principal's leadership skills referred to the school principal's capacity to design the educational service that the vocational high school under his or her reign should provide. In addition, the school principal should also have the capacity to influence and to invite the teachers and the educational staffs to change and to deliver the stipulated vision by optimizing the learning and growth perspective that became the core of intangible asset (human resources) so that the vocational high school might create learning innovations that would support the performance improvement and the institutional growth of the vocational high school as well as the achievement of internal process perspective, customer perspective and financial perspective.

The implementation of principal's managership skills was shown through the following aspects: (1) financial perspective by performing transparent and accountable school fund management; (2) customer perspective by establishing school business partnership; (3) internal process perspective by performing management on the partnership program, educators/educational staffs empowerment, facility maintenance and monitoring and evaluation efforts toward the school activities in order that the activities would meet the already defined objectives; and (4) learning and growth perspective by performing management on the side aspect of human resources. In the implementation of managership skills, the principal should be able to maintain the regular activities within the process of providing the educational service technically through the four perspectives in the Balanced Scorecard in order that the educational service might be effectively and efficiently implemented. The provision of educational service should be started by the control on the human resources that had not been in accordance with the organizational regulations/the side aspect management of human resources that lied on the learning and growth perspective and, later, the side aspect management would empower the performance in the internal process perspective, the customer perspective and the financial perspective.

The implementation of principal's communication skills had been the key of success in the implementation of Balanced Scorecard model for the vocational high school education because the principal's communication through the stipulated strategies connected all aspects that became the core of attention in the implementation of principal's leadership skills to all aspects that became the core of attention in the implementation of principal's managership skills. The principal's communication was conducted toward the internal stakeholders in order to deliver the solid teamwork by sharing the vision, the mission and the strategies of the vocational high school; in the same, the principal's communication was also conducted toward the external stakeholders as a form of job partnership in 
order to generate well-qualified and progressive vocational high school graduates.

The heaviest task that a principal had as a leader was to serve as problem solver and decision taker who should be able to decide the appropriate organizational direction. In order to support the task, the principal should implement the managerial control. The managerial control would work if there had been deviation between the job standards and the performance; as a result, the affectors would analyze the causes of deviation, would select the effective actions and then would implement and would measure the results of the action. The results of action implementing would then be the learning. The learning that had been attained by the managerial board of vocational high schools would be proceeded toward the development of vocational high schools' macro capacity, institution, educators and educational staffs and partnership. In addition, the learning would be a form of capability expansion (coming out of the comfort zone) of the vocational high school's principal.

The results of Balanced Scorecard model development for the vocational high school education had been the combination of Balanced Scorecard theory by Kaplan \& Norton and managerial control system theory by Anthony \& Govindarajan. The resulted Balanced Scorecard model for the vocational high school education had been an approach that might be implemented for identifying and for measuring the main performance of vocational high schools through the four perspectives namely the financial perspective, the customer perspective, the internal process perspective and the learning and growth perspective.

\section{Conclusions}

Based on the study of Balanced Scorecard model development, the researcher would like to draw the following conclusions. First, the implementation of Balanced Scorecard principles in the vocational high school has been shown by the integration of eight Educational National Standard (also known as SNP) criteria that are influenced by the four perspectives of Balanced Scorecard in the managerial planning and control system.

Second, the implementation model of vocational high school principal's leadership skills in the Balanced Scorecard vocational education management has been shown by performing the trendwatching development, the envisioning efforts, the mindset formation and the decision taking actions. The model of principal's managerial leadership implementation has been shown in the school working program management, educators/educational staffs empowerment, facility maintenance, school business partnership, school budget, side aspect of human resources and monitoring and evaluation efforts toward the strategic planning. The model of principal's communication leadership implementation has been shown by the communication of vocational high school strategies as a form of adjustment between the vocational high school strategies toward all of the school members and educational stakeholders of vocational high schools.

Third, the Balanced Scorecard model that is appropriate for the vocational high school education should be a system that might be implemented for identifying and for measuring the vocational high school performance through the four perspectives of Balanced Scorecard (the financial perspective, the customer perspective, the internal process perspective and the learning and growth perspective). The Balanced Scorecard model for the vocational high school education should also assist the managerial board in designing the managerial planning and control system for the vocational high school in accordance with the SNP strategically, provide directions (human capital, organization capital and information capital) and decrease the future uncertainty in the educational service provision by the educational practitioners. In additiopn, the Balanced Scorecard model should serve as source of information for the short-tem, mid-term and long-term educational plan and objectives that the vocational high schools pursue and 
should measure the progress in terms of vocational high school's input-output altogether in the same time.

Fourth, the Balanced Scorecard maudel for the vocational high school education that has been proposed has met the criteria of high model's internal effectiveness, namely 90.21; the score belongs to the very good category and, therefore, the model might be implemented as a model of vocational high school managerial implementation.

The suggestions that the researcher would like to deliver are as follows. First, the government (the Vocational High School Education/the Office of Education) is expected to facilitate the socialization or the implementation of Balanced Scorecard model in the respective working regions. Second, the future studies might work on the Balanced Scorecard development for the vocational high school education with focus on the expansion of Balanced Scorecard perspectives on the school's social responsibilities and the establishment of entrepreneurship spirit. Third, the vocational high school principals might adopt the Balanced Scorecard model for the vocational high school education in the vocational education management so that the vocational high school performance might be improved.

\section{References}

Anthony, R., \& Govindarajan, V. (2007). Management control systems. Boston: McGraw-Hill.

Armstrong, M. (2003). Strategic human resource management. Jakarta: PT Gramedia.

Borg, W. R., \& Gall, M. D. (1983). Educational research: An introduction (4th ed.). New York: Longman Publishing.

Campbell, D., Datar, S., Kulp, S. C., \& Narayanan, V. G. G. (2002). Using the balanced scorecard as a control system for monitoring and revising corporate strategy. SSRN Electronic Journal,
September.

https:// doi.org/10.2139/ssrn.328880

David, F. R. (2009). Strategic management. Jakarta: Salemba Empat.

Face to Face with Desi Anwar. (2013). Interview Desi Anwar with Robert S. Kaplan-Balanced scorecard. Indonesia: Metro TV. Retrieved from http://metronews.com/videoprogra m/detail/2013/02/23/1639/385/Rob ert-S-Kaplan/Face-to-Face-with-desianwar

Hendrawati, A., \& Prasojo, L. D. (2015). Pengaruh kepemimpinan transformasional kepala sekolah, motivasi kerja guru, dan budaya sekolah terhadap prestasi belajar. Jurnal Akuntabilitas Manajemen Pendidikan, 3(2), 141-157. Retrieved from

http://journal.uny.ac.id/index.php/j amp/article/view/6331

Kaplan, R. S., \& Norton, D. P. (1992, January). The balanced scorecardmeasures that drive performance. Harvard Business Review.

Kaplan, R. S., \& Norton, D. P. (2010). Execution premium. Jakarta Selatan: PT Ufuk Publishing House.

Mathis, R. L., \& Jackson, J. H. (2009). Human resource management. Jakarta: Salemba Empat.

Mulyadi. (2007). Sistem perencanaan dan pengendalian manajemen; sistem pelipatganda kinerja perusahaan. Jakarta: Salemba Empat.

Robbins, S. P., \& Coulter, M. (2010). Manajemen (Terjemahan Bob Sabran $\mathcal{E}$ Devri Barnadi Putera) (10th ed.). Jakarta: Erlangga.

Rustomji, M. K., \& Parkinson, C. N. (1993). Manajemen efektif: kunci mencapai hasil yang terbaik. Semarang: Dahara Prize.

Sugiyono. (2009). Metode penelitian kuantitatif, kualitatif, dan $R \quad \mathcal{E} D$. Bandung: Alfabeta. 